NEW RED STAR.-Mir. Birmingham, Millbrook, Tuam, mentions $(A . N ., 2,092)$ his having remarked an intensely red star, 8.5 magnitude, which is not in Schjellerup's catalogue (Vierteljahrschrift der Astron. Gesellschaft, ix. Jahrgang, Heft 4). From the approximate position given the star appears to be No. $3,568,+36^{\circ}$ in Durchmusteruno, where it is also estimated 8.5 , and its position $1855^{\circ} \mathrm{O}$ is R.A. $18 \mathrm{~h} .27 \mathrm{~m}$. I9s., N.P.D. $53^{\circ} 7^{\prime}$. It has not been found in any other catalogue.

THE DOUbLE STAR \& 3,121.--This object well merits the attention of observers who are in the possession of large telescopes. Baron Dembowski seems to have given it up for the present as beyond his instrumental means. It is evidently a binary of no long period. For comparison we have--

\begin{tabular}{|c|c|c|c|c|}
\hline Struve & 1832.31 & Position & $20 \%$ & Distance 0.85 \\
\hline bowski. & $1866 \cdot 22$ & $\pi$ & 189.7 & 0.68 \\
\hline$"$ & $\begin{array}{l}1872: 23 \\
1875 \cdot 31\end{array}$ & , & $\begin{array}{l}210.5 \\
252.0\end{array}$ & a wedge \\
\hline
\end{tabular}

The place of this star for 1876.0 is in R.A. $9 \mathrm{~h}$. Iom. 32s., N.P.D. $60^{\circ} 53^{\prime} \cdot 8$.

\section{THE LOAN COLLECTION CONFERE.VCES.}

$T \mathrm{HE}$ work in connection with the South Kensington Conferences has been carried on heartily and successfully during the past week. The number of visitors to the collection has been, all things considered, satisfactory, and the conference-room is always well filled.

Of the papers in the Section of Mechanics read on the I7th inst., M. Tresca's, on the "Flow of Solids," possessed some novelty and interest. From his experiments he drew inferences as to the proper form and mode of application of tools, explained the theory of many of the adjustments which workmen have found out by rule of thumb, and indicated extensions of the use of the principles now reduced into formulæ. He added that, in his belief, these mechanical laws ought to be pursued into physiology, and that the accretion of cell to cell was a mechanical phenomenon.

The conversazione given by the Physical Society the same evening was brilliant and successful.

At the meeting of the Chemical Section last Thursday, Dr. Frankland gave a long and highly important address, mainly on eudiometric apparatus. This address we give this week in extenso. Dr. J."H. Gilbert, F.R.S., then gave an interesting lecture on "Some Points connected with Vegetation." Mr. W. F. Donkin, M. A., then gave a description of the ozone apparatus of Sir B. Brodie, Bart., F.R.S., after which Prof. Andrews, F.R.S., concluded the meeting with an account of some experimental investigations in connection with the physical constitution of gases.

On Friday was held the second Conference in connection with the Physical Section. The conference-room throughout the day was unusually well filled. The first communication was from Prof. Tyndall, F.R.S., on the "Reflection of Sound." With the help of Mr. Cotterell, his assistant, he reproduced some of the experiments with sensitive flames with which he has made scientific audiences so familiar.

Dr. Stone spoke on the subiect of "Just Intonation and the Limits of Audible Sound." Mr. R. H. M. Bosanquet, M.A., spoke on "Instruments of Just Intonation," and explained the construction of the enharmonic harmonium contributed by him to the collection.

Mr. F. Galton, F.R.S., in his remarks "On the Limits of Audible Sound," spoke of experiments which he had been trying for some time past on the susceptibility of various animals to the highest notes, such as those of extremely small whistles. He had arrived at the conclusion that no animals were so sensitive to sounds of the character in question as cats, which, of course, were the ani- mals produced by natural selection to prey upon those other animals which in nature produced such soundsnamely, mice.

Prof. W. G. Adams, F.R.S., spoke on the late Sir C. Wheatstone's acoustical discoveries, and Mr. W. Chappell followed with a discourse "On Ancient Musical Science."

Mr. J. Baillie Hamilton spoke on Æolian instruments. He gave a history of the attempts in Europe to combine wind and string, and coming down to the present time he spoke of his own experiments. He has found that a metallic ring of suitable elasticity well supplies the place of a string's constraint on a vibrator. Variations in the shape of the ring produce differences of tone. Thus, passing from the circle to almond-shaped rings, all qualities from the flute to the horn are created.

M. Tresca referred to the still existing monuments of the history of science. For various reasons, want of appreciation, want of care, \&c., many instruments of historical interest are lost. France is relatively well off in its historical instruments, and it is well represented in this exhibition. M. Tresca then referred to the instruments in the collection France has sent over, giving a graphic sketch of their history and the history of the progress of the sciences they have helped forward. The Earl of Rosse, F.R.S., made a brief communication on the thermopiles which he is now using in connection with the telescopes belonging to the late Earl, after which Mr. De la Rue described his electric batteries of a novel construction. The Cavaliere Prof. De Eccher made a communication on the instruments sent over from Italy.

The conversazione given by the Geographical Society on Saturday evening was in all respects a successful one ; more than 2,000 persons accepted the invitations sent out.

In the second meeting of the Mechanical Section on Monday, the first paper was by Prof. Kennedy, or "Reuleaux's Collection of Kinematic Models." Prof. Kennedy explained the general principles and some of the details of these educational models designed by their constructor for the illustration of the theory of machines. Mr. W. Barnaby, C.B., then read a paper on "Naval Architecture," which we hope to publish in our next number. Mr. W. Froude, F.R.S. then gave a short lecture on "Fluid Resistance," detailing many of his experiments. The other papers read were by Mr. Thomas Stevenson, on "Lighthouses," M. le Général Morin on "Ventilation," Messrs. Dent on "Time-measurers," and Mr. J. N. Douglass, C.E., on "Instruments contributed by the Trinity House."

The Chemical Section met again on Tuesday. The President, Dr. Frankland, F.R.S., sead a communication from M. le Professeur Fremy, the French Chernist, on the Diminution of Scientific Research. M. Frémy has founded and carried on during the last twelve years a laboratory for the prosecution of original investigations by students who have completed their scientific studies. The experience which he has gained is such as to lead him to the conclusion that it is necessary to invoke state aid in order to restore research to that position which it should occupy. As the State chooses its officers and engineers after a severe course of study, and then ensures their regular advancement in its service, $M$. Frémy claims a similar boon on behal of pure science, which renders such invaluable services to the community. He proposes that the scientific service should consist of five grades, with salaries rising from a minimum of $120 l$. to $800 l$. per annum, and that the fitness of candidates for entrance to it should be decided by a jury of men of acknowledged scientific reputation, independence, and integrity. This jury should make known in official reports the claims of the various candidates to advancement, thus securing public criticism, and removing all opportunities of intrigue or favour. Prof. Roscoe, F.R.S., then gave a lecture on Vanadium and its Compounds, exhibiting on the table the collection of these substances 
contributed by himself to the Loan Collection, representing the results of bis admirably conducted series of researches in conneciion with this particular one of those metals designated by the chemist as "rare." The President, in thanking Prof. Roscoe, remarked, in reference to the value of scientific research, that it could not be t:o widely known that all the greatest results to which it had conduced had been obtained primarily by devotion to purely abstract science-practical applications having unexpectedly followed upon discovery. Prof. Guthrie, F.R.S., then gave an account of his researches on "Cryohydrates and Water of Crystallisation," a subject on which he has been working for the last three years. Prof. Williamson, F.R.S., gave an address on the "Manufacture of Steel," limiting his attention chiefly to the modes devised for the obviation and repression of the escape of carbonic oxide gas from molten steel during the casting and cooling process, after leaving the Bessemer or Siemens-Martin furnace. Mr. W. C. Roberts, F.R.S., subsequently read a paper, on the "Apparatus used by the late Prof. Graham in his Researches." The principal interest attaching to these pieces of apparatus was the simplicity of the means by which the late Master of the Mint established such important discoveries as the law of the diffusion of gases, the principle of the endosmotic action of fluids, and the consequent division of chemical substances into crystalloids and colloids. Mr. W. N. Hartley read a paper on the existence of "Liquid Carbonic Acid in the Cavities of Crystals," Dr. Gladstone, F.R.S., following with a short address on the electrolysis of organic compounds with the copper zinc couple. Dr. Frankland, in closing the Chemical Conference, congratulated the audience upon the success which had attended the proceedings throughout the two meetings.

Yesterday the Section of Physics met for the third time, when the following papers were to be read:-

Prof. J. Clerk Miaxwell, "On the Equilibrium of Heterogeneous Bodies ;" Prof. Andrews, "On the Liquid and Gaseons States of Bodies;" M. Sarasin-Diodati, "On M. de la Rive's Experiments in Statical Electricity ;" M. Lemström, "Sur l'Aurore Boréale ;" Baron F. de Wrangell, "On a New Form of Voltameter ;" Il Commendatore Professore Blaserna, "Sur l'état Variable des Courants Electriques :" Mr. Warren de la Rue, "On Astronomical Photosraphy;" Mr. Ranyard, "On the Instruments lent by the Royal Astronomical Society ;" Mr. Brooke, "On Magnetic Registration, and on the Corrections of the Magnetometers;" Prof. Carey Foster, "On Electrical Measurements " Herr Prof. Dr. Rijke, "On the Historical instruments from Leyden and Cassel;" the Rev. R. Main, "On a Telescope of Sir W. Herschel's."

The third meeting of the Mechanical Section is held to-day.

The first meeting in the Section of Biology will take place to-morrow, when the following papers will be read :Dr. J. B. Sanderson, the President, "On Methods of Physiological Measurement and Registration;" Prof. Marey "On various Instruments for Investigating and Pegistering Vital Movements;" Dr. Hooker "On the Plan of the New Laboratory for Investigations relating to the Physiology of Plants at Kew ; "Prof. Dyer "On various Apparatus for Investigating and Registering the Growth of Plants contributed by the Phy siological Laboratory of Bremen;" Dr. P. L. Sclater "On Drawings contributed by the Zoological Sociely;" Dr. Brunton "On a new Myographic Apparatus;" Dr. Klein "On Recording Apparatus exhibited by the Physiological Institute of the University of Prague ;" M. E. A. Schafer "On recent Improvements in Recording Apparatus."

The Science and Art Department are organising a series of popular lectures to be given on the evenings of the free days. Demonstrations of the objects in the galleries are also now given by the exhibitors or other competent persons at frequent intervals during the day.
SECTION-CHEMISTRY.

Opening Address by the President, Dr. Frankland, F.R.S.

THE Conference which I have been requested to open to-day has for its object the discussion of the merits and defects of the various forms of chemical apparatus exhibited in these buildings; and the criticism of the original investigations which are here illustrated, partly by the instruments used in them, and partly by the chemical compounds, to the discovery of which they have led.

Various objects interesting to chemists have been displayed in former international exhibitions, but it may be safely asserted that such a collection as this, which has been brought together in these buildings, has never before been seen ; neither has there before been the opportunity for discussion and criticism, by men eminent in science from all parts of Europe, which is now afforded.

Such a collection of apparatus and products, gathered from all parts of Europe is useful in disclosing, to chemical investigators and others, the best sources whence to procure apparatus; it is interesting historically and as showing the improvements in chemical apparatus during the present century; and it is instructive in the comparisons it affords of the various forms of instruments used for the same purpose in different countries, and by different experimenters.

The entire novelty of such a collection as that belonging to this section has rendered the attainment of the object sought for, on the present occasion, exceedingly difficult. The workers in science have hitherto had no inducement to preserve the instruments with which they experimented. When an investigation was finished the apparatus employed was dismantled and converted to other uses. Still less inducement has there been to preserve the chemical compounds resulting from research, although their creation required, in many cases, a great expenditure of time and labour. The chief object of preparing such compounds has hitherto been, in most cases, merely to ascertain their existence, to show their molecular relations to previously known bodies, and to ascertain a few of their leading properties such as colour, specific gravity, vapour density, melting point, boiling point, and chemical composition. They have been weighed and measured and then dismissed out of existence. And thus the present collection of chemical preparations is but the merest skeleton of a complete exposition of all known chemical compounds.

It is, indeed, remarkable, that whilst natural chemical compounds are exhibited in almost endlessly multiplied specimens in the mineralogical collections of our national museums, the artificial compounds which have resulted from research, or have been the foundation of important theories and generalisations, have nowhere been honoured by admission into national collections. The neglect, not to say contempt, with which these productions of the laboratory have been treated, cannot be justified on the ground of their want of national utility. It is true that from an exclusively commercial point of view, no one of them can lay claim to the importance of coal, iron, silver, and gold. Still, many of them, such as the paraffins, the coal-tar colours, and many of the compounds of sulphur, potassium, sodium, and ammonium, have contributed, in an important degree, to the wealth and prosperity of this and other states. Had these artificial compounds remained undiscovered, how different would now have been the condition of the industries of bleaching, dyeing, calico-printing, glass-making, and the manufactures connected with the production of artificial light. Many of these artificial compounds have become of the most essential importance to the physician, the artist, the telegraphist, the engineer, and the manufacturer, and it cannot be doubted that many more would soon come into active service for such purposes if they were better known. 